\title{
Parkinson's Disease, Smoking, and Lower Endoscopy
}

Susan M. Davis (sumada@verizon.net)

\begin{abstract}
Parkinson's disease (PD) is inversely associated with smoking. Whether this association is due to a causal relationship or to confounding by a covariate of smoking is still debated.

The Institute for Health Metrics and Evaluation (IHME) released refreshed data on October 15, 2020. This study included that recently released data. The study included populations of the United States and ten U.S. states from 2004 to 2018. The ten U.S. states included the five states with the highest PD incidence rates in 2019 (Maine, Vermont, Kansas, Alaska, Missouri) and the five states with the lowest PD incidence rates in 2019 (Arkansas, Mississippi, South Dakota, Nebraska, Delaware). The study used scatter plots to explore the association between PD incidence and smoking and the association between PD incidence and a covariate of smoking, lower endoscopy utilization.
\end{abstract}

For PD verses smoking, the results indicate that there is an inverse correlation for the United States, but there is no association for the ten states. The coefficient of determination $\left(R^{2}\right)$ for the United States was 0.714 and ranged from a low of 0.004 for South Dakota to 0.613 for Mississippi. The average $\mathrm{R}^{2}$ for the ten states was 0.357 .

For PD verses lower endoscopy, the results indicate that the best model fit to the data is a polynomial. When the fitting curve examined in the regression analysis was a 3rd order (cubic) polynomial, there was a positive correlation between PD and lower endoscopy for the United States and for all ten states. The $\mathrm{R}^{2}$ for the US was 0.971 and ranged from a low of 0.709 for Alaska to 0.970 for Kansas. The average $\mathrm{R}^{2}$ for the ten states was 0.878 .

The results suggest that the inverse association between PD incidence and smoking is confounded by a positive association between PD and lower endoscopy utilization. Further investigation of a possible relationship between PD incidence and lower endoscopy utilization is warranted and may provide a means for reducing PD incidence. 
medRxiv preprint doi: https://doi.org/10.1101/2020.11.10.20229450; this version posted November 13, 2020. The copyright holder for this preprint (which was not certified by peer review) is the author/funder, who has granted medRxiv a license to display the preprint in perpetuity.

It is made available under a CC-BY 4.0 International license .

\section{INTRODUCTION}

Parkinson's disease (PD) incidence rates have been increasing [1]. There is no known cause for most cases of PD, and they are thought to result from a complex combination of many factors, including industrialization, environmental toxins, lifestyle, genetics, and age [2-3].

PD is related to smoking, with current smokers having a lower risk for PD when compared to never smokers [2-4]. Of eighty-four risk factors explored by the Global Burden of Diseases, Injuries, and Risk Factors (GBD), smoking was the only risk factor deemed to have a relationship with PD [2]. The inverse relationship between PD and smoking may be causal or it may be due to confounding by a covariate of smoking.

One covariate of smoking is colorectal cancer (CRC) screening. Several studies have found that current smokers are less likely to participate in CRC screening compared to never smokers [5-9]. In the United States, the most commonly used CRC screening test is colonoscopy [10]. Compared with never smokers, current smokers are less likely to ever have received a colonoscopy [5].

Colonoscopy is a lower endoscopic procedure that examines the entire colon, and precancerous polyps can be removed during the procedure, thereby reducing CRC risk [11-12]. Another lower endoscopic procedure used for CRC screening is sigmoidoscopy, which is similar to colonoscopy, but examines only a portion of the colon [12-13].

A previous study that explored the association between PD incidence and smoking and the association between PD incidence and lower endoscopy utilization posted on MedRxiv on September 23, 2020 (https://medrxiv.org/cgi/content/short/2020.09.20.20198390v1). That study included data obtained from the Institute for Health Metrics and Evaluation (IHME)'s Global Burden of Diseases, Injuries, and Risk Factors (GBD) Compare visualization system on September 15, 2020. (Data used in that study is now available at https://gbd2017.healthdata.org/gbd-compare/). That study concluded that the inverse association between PD incidence and smoking is confounded by a direct association between PD and lower endoscopy utilization.

On October 15, 2020, the IHME refreshed the data to reflect the new results from the GBD 2019 (available at https://vizhub.healthdata.org/gbd-compare). The present study included this refreshed data. 
medRxiv preprint doi: https://doi.org/10.1101/2020.11.10.20229450; this version posted November 13 , 2020. The copyright holder for this preprint (which was not certified by peer review) is the author/funder, who has granted medRxiv a license to display the preprint in perpetuity.

It is made available under a CC-BY 4.0 International license .

\section{METHODS}

The present study comprises scatter plots of PD incidence versus current smoking and PD incidence versus lower endoscopy utilization for different populations.

This study included populations of the United States (all 50 states and the District of Columbia) and ten U.S. states from 2004 to 2018. The ten U.S. states included the five states with the highest PD incidence rates in 2019 (Maine, Vermont, Kansas, Alaska, Missouri) and the five states with the lowest PD incidence rates in 2019 (Arkansas, Mississippi, South Dakota, Nebraska, Delaware). Compared to the previous study, Colorado was replaced by Alaska in the group of five states with the highest PD incidence rates, and Alabama was replaced by Delaware in the group of five states with the lowest PD incidence rates.

PD incidence rates (age standardized, new cases per 100,000) were obtained from the Institute for Health Metrics and Evaluation (IHME)'s Global Burden of Diseases, Injuries, and Risk Factors (GBD) Compare visualization system (available at https://vizhub.healthdata.org/gbd-compare) [14]. Methodology, sample size, and 95\% confidence intervals may be obtained from the IHME.

Rates of current smoking (\% adults who are current smokers) were obtained from the Centers for Disease Control and Prevention (CDC)'s Behavioral Risk Factor Surveillance System (BRFSS) Web Enabled Analysis Tool (WEAT) (available at https://www.cdc.gov/brfss/data tools.htm) [15]. For 2004, the column variable for current smoking was "Tobacco Use: Calculated variable for adults who are current smokers (_RFSMOK2)". For all other years, the column variable for current smoking was "Tobacco Use: Calculated variable for adults who are current smokers (_RFSMOK3)". Methodology, sample size, and $95 \%$ confidence intervals may be obtained from the CDC.

Rates of lower endoscopy utilization (\% who ever had a sigmoidoscopy/colonoscopy) were obtained from the Centers for Disease Control and Prevention (CDC)'s Behavioral Risk Factor Surveillance System (BRFSS) Web Enabled Analysis Tool (WEAT) (available at https://www.cdc.gov/brfss/data tools.htm) [15]. The column variable for lower endoscopy utilization was "Colorectal Cancer Screening: Ever had a sigmoidoscopy/colonoscopy (HADSIGM3)". Methodology, sample size, and 95\% confidence intervals may be obtained from the CDC.

This study included the years 2004, 2006, 2008, 2010, 2012, 2014, 2016 and 2018, as those were the only years for which lower endoscopy utilization data were available from WEAT. The scatter plots, trendline equations and coefficients of determination $\left(R^{2}\right)$ were generated using Microsoft Excel. 
medRxiv preprint doi: https://doi.org/10.1101/2020.11.10.20229450; this version posted November 13, 2020. The copyright holder for this preprint (which was not certified by peer review) is the author/funder, who has granted medRxiv a license to display the preprint in perpetuity. It is made available under a CC-BY 4.0 International license .

\section{RESULTS}

Figures $1 \mathrm{a}$ and $1 \mathrm{~b}$ are scatter plots of PD verses smoking. Figure 1a shows the five states with the highest PD incidence rates in 2019 and the US. Figure 1b shows the five states with the lowest PD incidence rates in 2019 and the US.

Figures $2 \mathrm{a}$ and $2 \mathrm{~b}$ are scatter plots of PD verses lower endoscopy. Figure $2 \mathrm{a}$ shows the five states with the highest PD incidence rates in 2019 and the US. Figure $2 b$ shows the five states with the lowest PD incidence rates in 2019 and the US.

Table 1 shows the data plotted in the figures, and the trendline equations and $R^{2}$ values for linear fitting curves. Tables 2-4 show the trendline equations and $R^{2}$ values for $2 \mathrm{nd}$, 3rd and 4 th order polynomial fitting curves, respectively. 
medRxiv preprint doi: https://doi.org/10.1101/2020.11.10.20229450; this version posted November 13, 2020. The copyright holder for this preprint (which was not certified by peer review) is the author/funder, who has granted medRxiv a license to display the preprint in perpetuity.

It is made available under a CC-BY 4.0 International license .

Figure 1a: PD vs smoking for the five states with the highest PD incidence rates and the US.

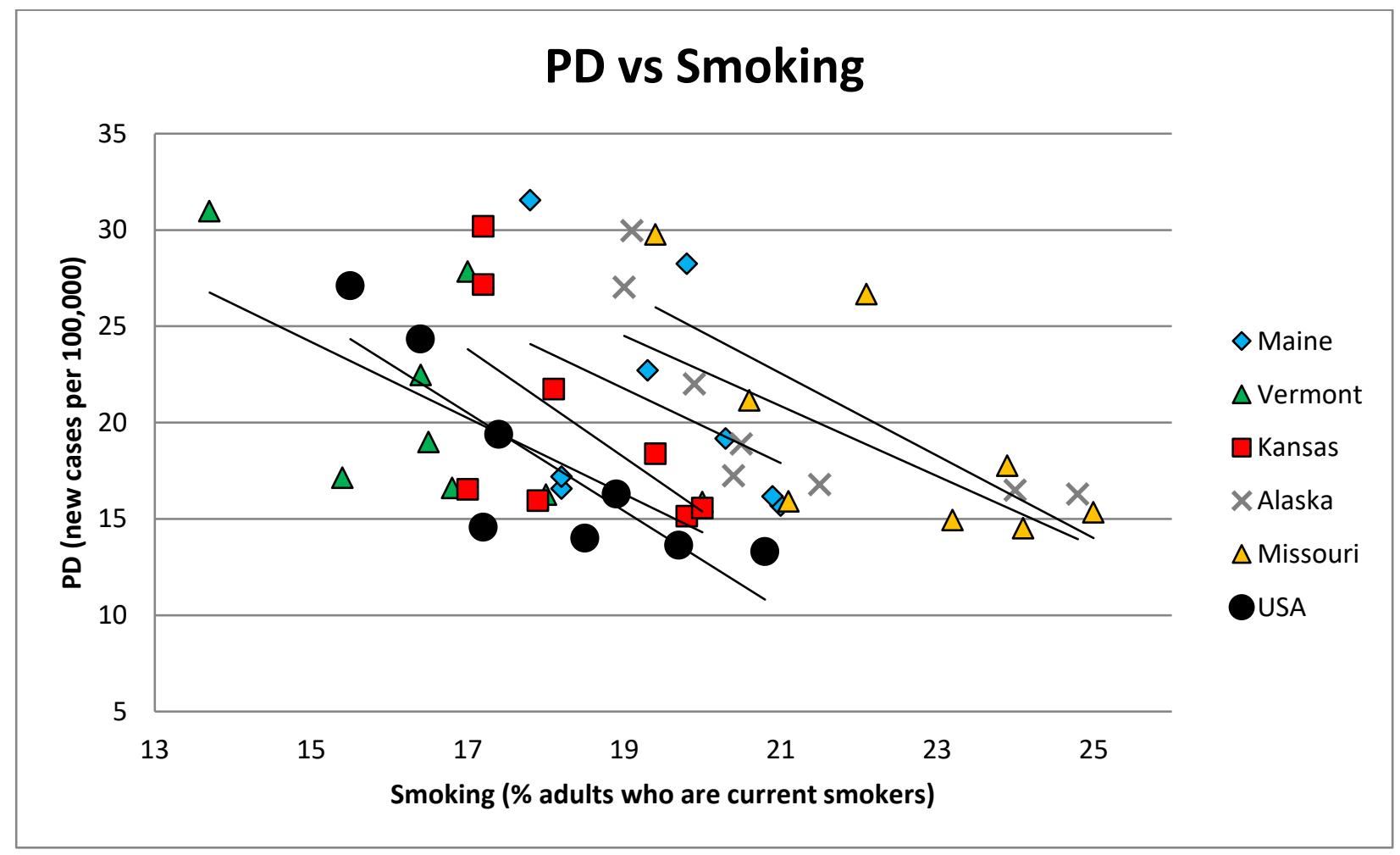

Figure 1b: PD vs smoking for the five states with the lowest PD incidence rates and the US.

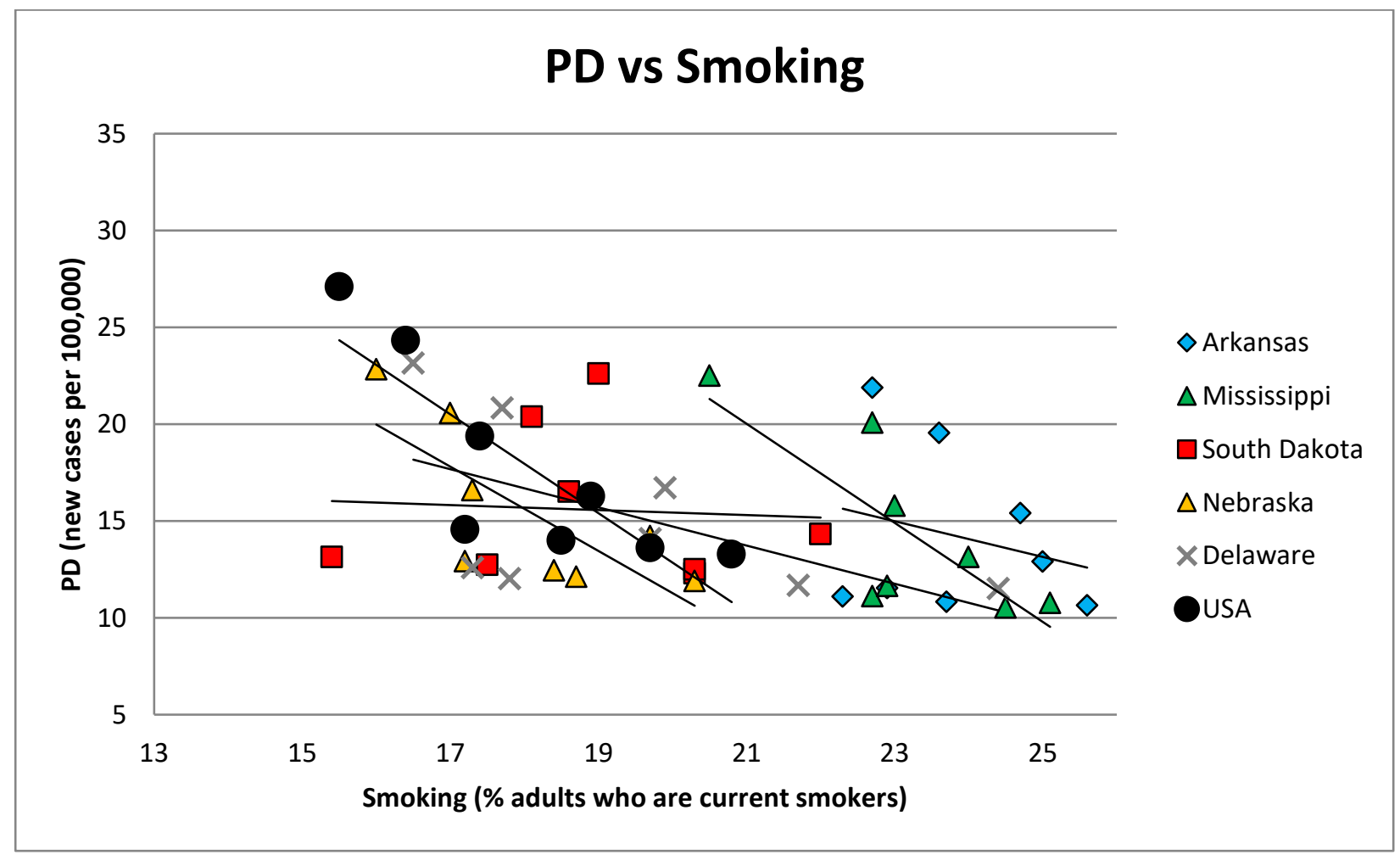


medRxiv preprint doi: https://doi.org/10.1101/2020.11.10.20229450; this version posted November 13, 2020. The copyright holder for this preprint (which was not certified by peer review) is the author/funder, who has granted medRxiv a license to display the preprint in perpetuity.

It is made available under a CC-BY 4.0 International license .

Figure 2a: PD vs lower endoscopy for the five states with the highest PD incidence rates and the US.

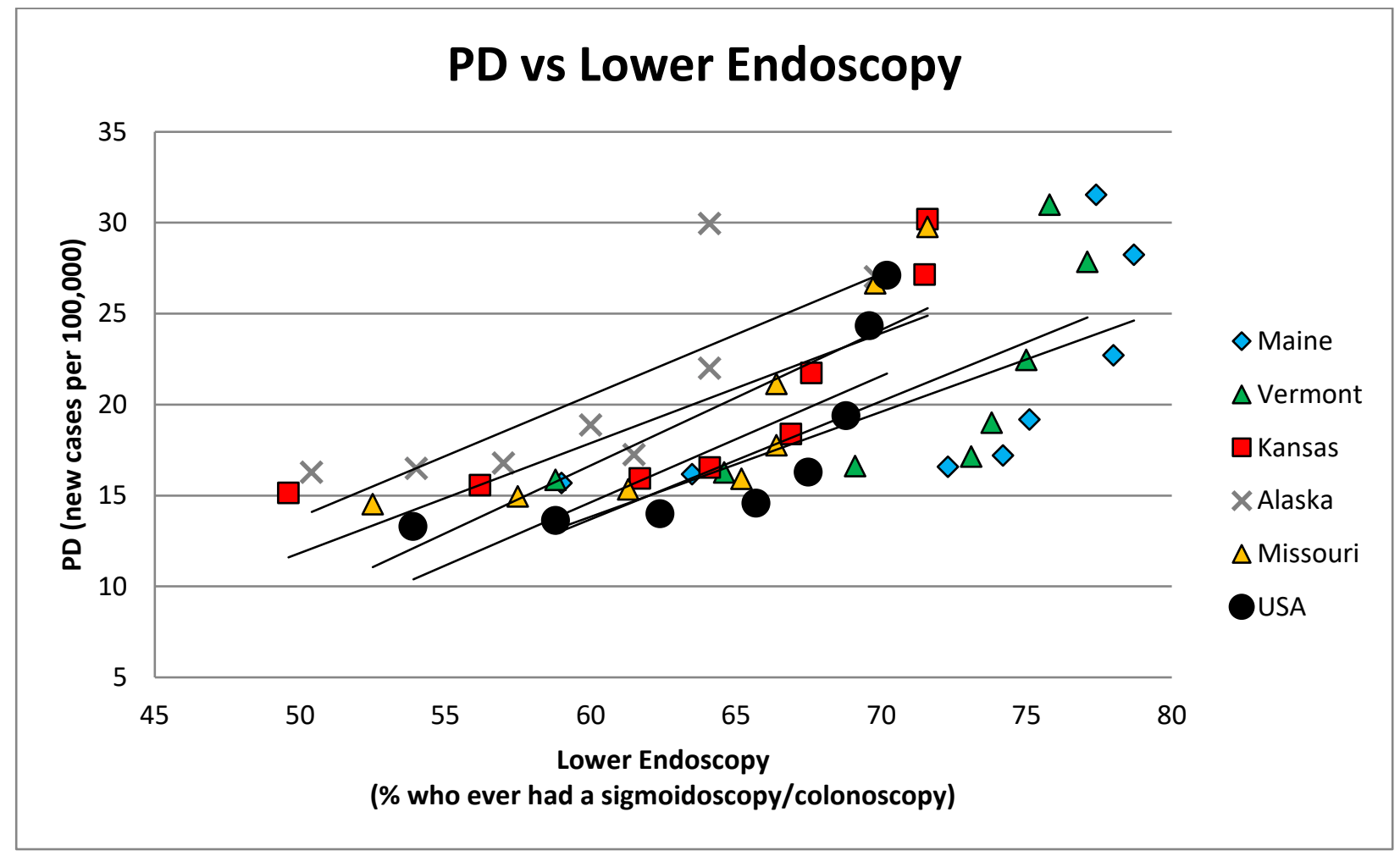

Figure 2b: PD vs lower endoscopy for the five states with the lowest PD incidence rates and the US.

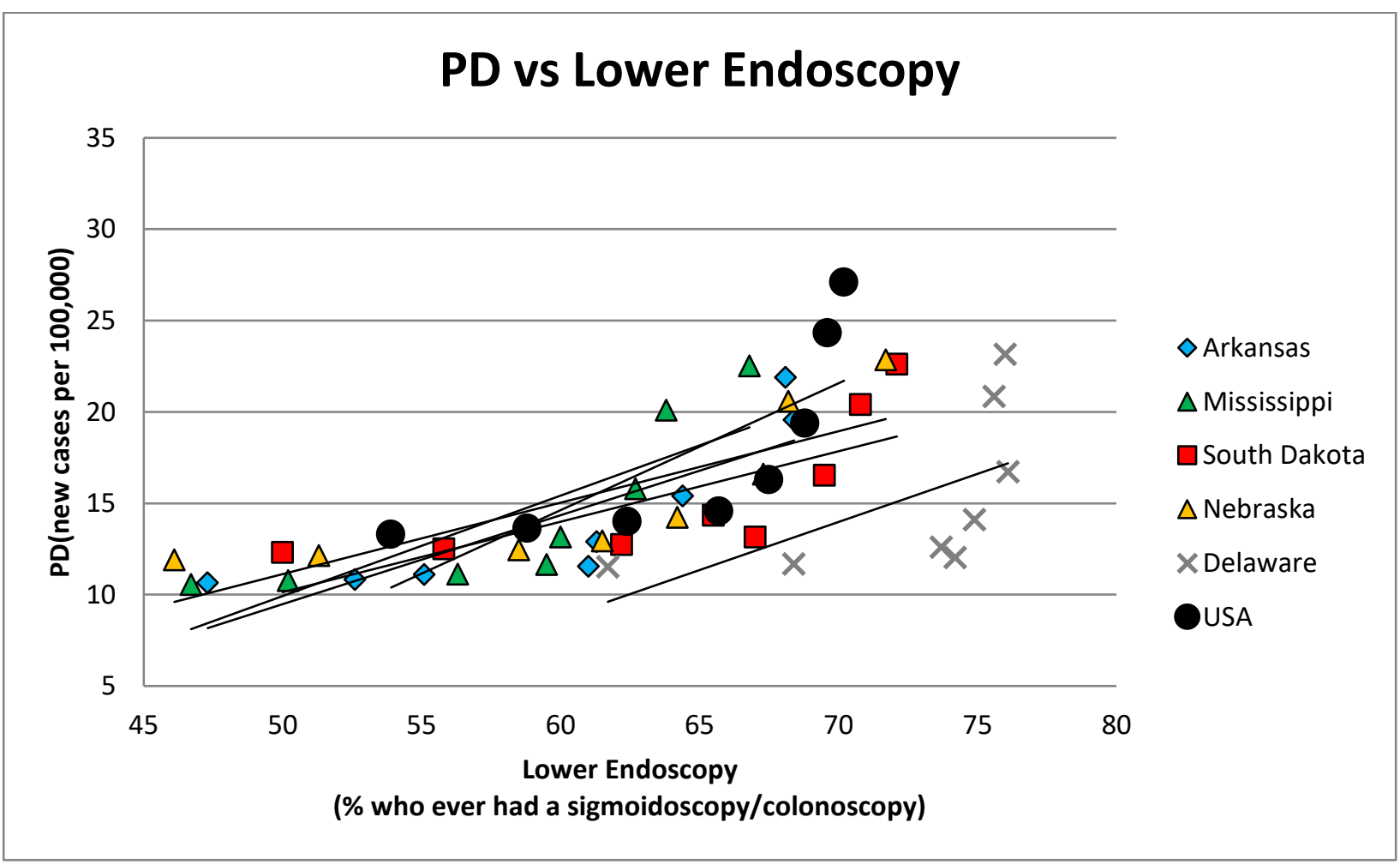


medRxiv preprint doi: https://doi.org/10.1101/2020.11.10.20229450; this version posted November 13, 2020. The copyright holder for this preprint (which was not certified by peer review) is the author/funder, who has granted medRxiv a license to display the preprint in perpetuity.

It is made available under a CC-BY 4.0 International license .

Table 1: Data plotted in Figures 1a,b and 2a,b; trendline equations and $\mathrm{R}^{2}$ values for linear fitting curves.

\begin{tabular}{|c|c|c|c|c|c|c|c|c|c|c|c|c|}
\hline \multicolumn{13}{|c|}{ Parkinson's Disease (age standardized, new cases per 100,000$)^{1}$} \\
\hline \multicolumn{4}{|r|}{2004} & 2006 & 2008 & 2010 & \multicolumn{2}{|c|}{2012} & 2014 & 2016 & 2018 & 2019 \\
\hline \multicolumn{3}{|c|}{ Maine (ME) } & 15.69 & 16.17 & 16.58 & 17.2 & \multicolumn{2}{|c|}{19.18} & 22.71 & 28.25 & 31.55 & 30.97 \\
\hline \multicolumn{3}{|c|}{ Vermont (VT) } & 15.87 & 16.27 & 16.62 & 17.14 & \multicolumn{2}{|c|}{19.0} & 22.47 & 27.85 & 30.99 & 30.45 \\
\hline \multicolumn{3}{|c|}{ Kansas (KS) } & 15.15 & 15.57 & 15.95 & 16.54 & \multicolumn{2}{|c|}{18.39} & 21.74 & 27.16 & 30.2 & 29.46 \\
\hline \multicolumn{3}{|c|}{ Alaska (AK) } & 16.29 & 16.49 & 16.78 & 17.25 & \multicolumn{2}{|c|}{18.89} & 22.0 & 27.04 & 29.96 & 29.44 \\
\hline \multicolumn{3}{|c|}{ Missouri (MO) } & 14.53 & 14.95 & 15.35 & 15.92 & \multicolumn{2}{|c|}{17.76} & 21.15 & 26.67 & 29.78 & 28.98 \\
\hline \multicolumn{3}{|c|}{ Arkansas (AR) } & 10.65 & 10.83 & 11.11 & 11.55 & \multicolumn{2}{|c|}{12.91} & 15.41 & 19.56 & 21.9 & 21.29 \\
\hline Missi & ippi (MS & & 10.55 & 10.78 & 11.13 & 11.66 & 13.1 & & 15.8 & 20.09 & 22.51 & 21.87 \\
\hline Soutt & Dakota (s & & 12.32 & 12.51 & 12.75 & 13.15 & 14.3 & & 16.53 & 20.4 & 22.62 & 22.05 \\
\hline Nebr & ka (NB) & & 11.91 & 12.14 & 12.46 & 12.94 & 14.2 & & 16.6 & 20.58 & 22.85 & 22.28 \\
\hline Delas & re (DE) & & 11.52 & 11.68 & 12.03 & 12.6 & 14. & & 16.73 & 20.85 & 23.16 & 22.66 \\
\hline Unite & States (1 & $S)^{a}$ & 13.3 & 13.63 & 14.0 & 14.57 & 16.2 & & 19.39 & 24.33 & 27.11 & 26.44 \\
\hline & & & & oking & adults & ho are & . & 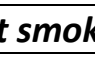 & kers) $)^{2}$ & & & \\
\hline & & & & & & & & & & $P D_{1}$ & Smoking & \\
\hline & 2004 & 2006 & 2008 & 2010 & 2012 & 2014 & 2016 & 2018 & Tren & ndline Equ & tion $^{\mathrm{b}}$ & $R$-squared ${ }^{b}$ \\
\hline ME & 21.0 & 20.9 & 18.2 & 18.2 & 20.3 & 19.3 & 19.8 & 17.8 & $y=-$ & $-1.929 x+$ & 8.41 & 0.163 \\
\hline VT & 20.0 & 18.0 & 16.8 & 15.4 & 16.5 & 16.4 & 17.0 & 13.7 & $y=-$ & $-1.975 x+$ & 3.81 & 0.389 \\
\hline KS & 19.8 & 20.0 & 17.9 & 17.0 & 19.4 & 18.1 & 17.2 & 17.2 & $y=-$ & $-2.808 x+$ & 1.54 & 0.361 \\
\hline AK & 24.8 & 24.0 & 21.5 & 20.4 & 20.5 & 19.9 & 19.0 & 19.1 & $y=-$ & $-1.819 x+$ & 9.07 & 0.558 \\
\hline MO & 24.1 & 23.2 & 25.0 & 21.1 & 23.9 & 20.6 & 22.1 & 19.4 & $y=-$ & $-2.138 x+$ & 7.47 & 0.509 \\
\hline$A R$ & 25.6 & 23.7 & 22.3 & 22.9 & 25.0 & 24.7 & 23.6 & 22.7 & $y=-$ & $-0.921 x$ & 6.18 & 0.063 \\
\hline MS & 24.5 & 25.1 & 22.7 & 22.9 & 24.0 & 23.0 & 22.7 & 20.5 & $y=-$ & $-2.557 x+$ & 3.73 & 0.613 \\
\hline SD & 20.3 & 20.3 & 17.5 & 15.4 & 22.0 & 18.6 & 18.1 & 19.0 & $y=-$ & $-0.129 x+$ & 8.01 & 0.004 \\
\hline NB & 20.3 & 18.7 & 18.4 & 17.2 & 19.7 & 17.3 & 17.0 & 16.0 & $y=-$ & $-2.175 x$ & 54.78 & 0.575 \\
\hline DE & 24.4 & 21.7 & 17.8 & 17.3 & 19.7 & 19.9 & 17.7 & 16.5 & $y=-$ & $-0.985 x+$ & 34.43 & 0.335 \\
\hline US $^{\mathrm{a}}$ & 20.8 & 19.7 & 18.5 & 17.2 & 18.9 & 17.4 & 16.4 & 15.5 & $y=-$ & $-2.551 x+$ & 63.87 & 0.714 \\
\hline & & LoI & er Endosc & py (\% & vho eve & had a si & igmoidc & oscopy & y/colon & oscopy) & & \\
\hline & & & & & & & & & & $P D v$ & Endoscop & \\
\hline & 2004 & 2006 & 2008 & 2010 & 2012 & 2014 & 2016 & 2018 & & ndline Equ & tion $^{\mathrm{b}}$ & $R_{\text {-squared }}{ }^{b}$ \\
\hline ME & 59.0 & 63.5 & 72.3 & 74.2 & 75.1 & 78.0 & 78.7 & 77.4 & & $=0.577 x$ & 20.78 & 0.475 \\
\hline VT & 58.8 & 64.6 & 69.1 & 73.1 & 73.8 & 75.0 & 77.1 & 75.8 & & $=0.649 x$ & 25.25 & 0.504 \\
\hline KS & 49.6 & 56.2 & 61.7 & 64.1 & 66.9 & 67.6 & 71.5 & 71.6 & & $=0.604$ & 18.36 & 0.640 \\
\hline AK & 50.4 & 54.0 & 57.0 & 61.5 & 60.0 & 64.1 & 69.8 & 64.1 & & $=0.668 \mathrm{x}$ & 19.57 & 0.615 \\
\hline Mo & 52.5 & 57.5 & 61.3 & 65.2 & 66.4 & 66.4 & 69.8 & 71.6 & & $=0.745 \mathrm{x}$ & 28.07 & 0.666 \\
\hline$A R$ & 47.3 & 52.6 & 55.1 & 61.0 & 61.3 & 64.4 & 68.4 & 68.1 & & $=0.486 x$ & 14.85 & 0.715 \\
\hline MS & 46.7 & 50.2 & 56.3 & 59.5 & 60.0 & 62.7 & 63.8 & 66.8 & & $=0.549 \mathrm{x}$ & 17.55 & 0.675 \\
\hline SD & 50.0 & 55.8 & 62.2 & 67.0 & 65.5 & 69.5 & 70.8 & 72.1 & & $=0.385 \mathrm{x}$ & 9.134 & 0.571 \\
\hline NB & 46.1 & 51.3 & 58.5 & 61.5 & 64.2 & 67.3 & 68.2 & 71.7 & & $=0.390 x$ & 8.412 & 0.671 \\
\hline DE & 61.7 & 68.4 & 74.2 & 73.7 & 74.9 & 76.1 & 75.6 & 76.0 & & $=0.526 x$ & 22.85 & 0.349 \\
\hline US $^{\mathrm{a}}$ & 53.9 & 58.8 & 62.4 & 65.7 & 67.5 & 68.8 & 69.6 & 70.2 & & $=0.694 x$ & 27.02 & 0.579 \\
\hline All & 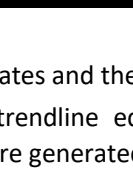 & 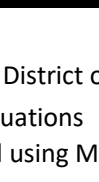 & . & 2 & J. & 年 & 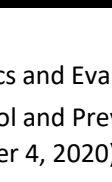 & 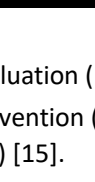 & , & essed I & 21 & $\begin{array}{l}\text { ) [14]. } \\
\text { Tool }\end{array}$ \\
\hline
\end{tabular}


medRxiv preprint doi: https://doi.org/10.1101/2020.11.10.20229450; this version posted November 13, 2020. The copyright holder for this preprint (which was not certified by peer review) is the author/funder, who has granted medRxiv a license to display the preprint in perpetuity.

It is made available under a CC-BY 4.0 International license .

Table 2: Trendline equations and $\mathrm{R}^{2}$ values for 2 nd order polynomial fitting curves.

2nd Order Polynomial

\begin{tabular}{|c|c|c|}
\hline & \multicolumn{2}{|c|}{ PD vs Smoking } \\
\hline & Trendline Equation $^{\mathrm{b}}$ & R-squared ${ }^{b}$ \\
\hline Maine & $y=-1.119 x^{2}+41.51 x-361.7$ & 0.198 \\
\hline Vermont & $y=0.314 x^{2}-12.58 x+142.3$ & 0.445 \\
\hline Kansas & $y=0.086 x^{2}-5.990 x+100.8$ & 0.361 \\
\hline Alaska & $y=0.970 x^{2}-44.37 x+520.8$ & 0.906 \\
\hline Missouri & $y=0.366 x^{2}-18.42 x+247.1$ & 0.545 \\
\hline Arkansas & $y=-1.293 x^{2}+61.00 x-703.4$ & 0.160 \\
\hline Mississippi & $y=0.330 x^{2}-17.63 x+245.3$ & 0.641 \\
\hline South Dakota & $y=-0.387 x^{2}+14.38 x-116.3$ & 0.209 \\
\hline Nebraska & $y=0.994 x^{2}-38.40 x+382.9$ & 0.764 \\
\hline Delaware & $y=0.152 x^{2}-7.195 x+96.62$ & 0.380 \\
\hline \multirow[t]{3}{*}{ United States a } & $y=0.690 x^{2}-27.62 x+289.4$ & 0.851 \\
\hline & \multicolumn{2}{|c|}{ PD vs Lower Endoscopy } \\
\hline & Trendline Equation $^{\mathrm{b}}$ & $R$-squared ${ }^{b}$ \\
\hline Maine & $y=0.087 x^{2}-11.50 x+391.0$ & 0.719 \\
\hline Vermont & $y=0.092 x^{2}-11.87 x+397.3$ & 0.747 \\
\hline Kansas & $y=0.060 x^{2}-6.779 x+203.5$ & 0.931 \\
\hline Alaska & $y=0.025 x^{2}-2.339 x+69.60$ & 0.649 \\
\hline Missouri & $y=0.082 x^{2}-9.462 x+285.5$ & 0.932 \\
\hline Arkansas & $y=0.043 x^{2}-4.621 x+132.0$ & 0.939 \\
\hline Mississippi & $y=0.060 x^{2}-6.263 x+172.1$ & 0.942 \\
\hline South Dakota & $y=0.046 x^{2}-5.267 x+161.2$ & 0.877 \\
\hline Nebraska & $y=0.033 x^{2}-3.568 x+105.4$ & 0.935 \\
\hline Delaware & $y=0.120 x^{2}-16.16 x+549.9$ & 0.581 \\
\hline United States a & $y=0.106 x^{2}-12.55 x+382.7$ & 0.851 \\
\hline
\end{tabular}

Notes:

a All 50 states and the District of Columbia.

${ }^{b}$ Polynomial trendline equations and R-squared values were generated using Microsoft Excel. 
medRxiv preprint doi: https://doi.org/10.1101/2020.11.10.20229450; this version posted November 13, 2020. The copyright holder for this preprint (which was not certified by peer review) is the author/funder, who has granted medRxiv a license to display the preprint in perpetuity.

It is made available under a CC-BY 4.0 International license .

Table 3: Trendline equations and $\mathrm{R}^{2}$ values for 3rd order polynomial fitting curves.

3rd Order Polynomial

\begin{tabular}{|c|c|c|}
\hline & \multicolumn{2}{|l|}{ PD vs Smoking } \\
\hline & Trendline Equation $^{\mathrm{b}}$ & $R_{\text {-squared }}^{\mathrm{b}}$ \\
\hline Maine & $y=-5.453 x^{3}+317.5 x^{2}-6152 \cdot x+39702$ & 0.662 \\
\hline Vermont & $y=-0.303 x^{3}+15.63 x^{2}-267.6 x+1543$ & 0.528 \\
\hline Kansas & $y=0.646 x^{3}-35.64 x^{2}+651 x-3918$ & 0.366 \\
\hline Alaska & $y=-0.225 x^{3}+15.60 x^{2}-359.2 x+2768$ & 0.941 \\
\hline Missouri & $y=-0.221 x^{3}+15.09 x^{2}-343.8 x+2633$ & 0.582 \\
\hline Arkansas & $y=0.390 x^{3}-29.35 x^{2}+731.8 x-6042$ & 0.167 \\
\hline Mississippi & $y=-0.024 x^{3}+2.023 x^{2}-56.12 x+535.9$ & 0.641 \\
\hline South Dakota & $y=0.125 x^{3}-7.426 x^{2}+144.7 x-914.3$ & 0.266 \\
\hline Nebraska & $y=-0.132 x^{3}+8.205 x^{2}-168.5 x+1162$ & 0.769 \\
\hline Delaware & $y=-0.089 x^{3}+5.663 x^{2}-118.7 x+841.5$ & 0.431 \\
\hline \multirow[t]{3}{*}{ United States ${ }^{\text {a }}$} & $y=-0.103 x^{3}+6.336 x^{2}-129.5 x+899.3$ & 0.858 \\
\hline & \multicolumn{2}{|l|}{ PD vs Lower Endoscopy } \\
\hline & Trendline Equation $^{\mathrm{b}}$ & R-squared $^{\mathrm{b}}$ \\
\hline Maine & $y=0.006 x^{3}-1.180 x^{2}+76.12 x-1615$ & 0.758 \\
\hline Vermont & $y=0.010 x^{3}-2.007 x^{2}+130.2 x-2791$ & 0.819 \\
\hline Kansas & $y=0.004 x^{3}-0.684 x^{2}+38.32 x-697.9$ & 0.970 \\
\hline Alaska & $y=-0.006 x^{3}+1.203 x^{2}-72.94 x+1469$ & 0.709 \\
\hline Missouri & $y=0.004 x^{3}-0.762 x^{2}+42.81 x-786.1$ & 0.953 \\
\hline Arkansas & $y=0.002 x^{3}-0.372 x^{2}+19.38 x-324.8$ & 0.960 \\
\hline Mississippi & $y=0.001 x^{3}-0.200 x^{2}+8.515 x-104.7$ & 0.947 \\
\hline South Dakota & $y=0.004 x^{3}-0.717 x^{2}+41.21 x-772.7$ & 0.959 \\
\hline Nebraska & $y=0.001 x^{3}-0.177 x^{2}+8.774 x-132.0$ & 0.950 \\
\hline Delaware & $y=0.032 x^{3}-6.682 x^{2}+452.6 x-10182$ & 0.753 \\
\hline United States a & $y=0.017 x^{3}-3.116 x^{2}+186.7 x-3704$ & 0.971 \\
\hline
\end{tabular}

Notes:

a All 50 states and the District of Columbia.

${ }^{b}$ Polynomial trendline equations and R-squared values were generated using Microsoft Excel. 
medRxiv preprint doi: https://doi.org/10.1101/2020.11.10.20229450; this version posted November 13, 2020. The copyright holder for this preprint (which was not certified by peer review) is the author/funder, who has granted medRxiv a license to display the preprint in perpetuity.

It is made available under a CC-BY 4.0 International license .

Table 4: Trendline equations and $\mathrm{R}^{2}$ values for 4 th order polynomial fitting curves.

4th Order Polynomial

\begin{tabular}{|c|c|c|}
\hline & \multicolumn{2}{|l|}{ PD vs Smoking } \\
\hline & Trendline Equation $^{\mathrm{b}}$ & $R$-squared ${ }^{b}$ \\
\hline Maine & $y=4.722 x^{4}-371.0 x^{3}+10917 x^{2}-14257 x+69732$ & 0.949 \\
\hline Vermont & $y=0.381 x^{4}-25.96 x^{3}+658.3 x^{2}-7380 . x+30876$ & 0.689 \\
\hline Kansas & $y=-7.587 x^{4}+564.3 x^{3}-15723 x^{2}+19442 x-90041$ & 0.639 \\
\hline Alaska & $y=0.005 x^{4}-0.721 x^{3}+31.83 x^{2}-594.6 x+4044$ & 0.941 \\
\hline Missouri & $y=0.364 x^{4}-32.67 x^{3}+1095 \cdot x^{2}-16269 x+90434$ & 0.724 \\
\hline Arkansas & $y=-1.558 x^{4}+149.8 x^{3}-5397 . x^{2}+86389 x-51812$ & 0.254 \\
\hline Mississippi & $y=0.167 x^{4}-15.47 x^{3}+536.8 x^{2}-8271 . x+47762$ & 0.642 \\
\hline South Dakota & $y=0.373 x^{4}-28.01 x^{3}+783.8 x^{2}-9687 . x+44629$ & 0.775 \\
\hline Nebraska & $y=-0.545 x^{4}+39.36 x^{3}-1061 . x^{2}+12677 x-56531$ & 0.832 \\
\hline Delaware & $y=0.085 x^{4}-7.010 x^{3}+213.6 x^{2}-2878 . x+14485$ & 0.583 \\
\hline \multirow[t]{3}{*}{ United States ${ }^{a}$} & $y=-0.121 x^{4}+8.709 x^{3}-232.3 x^{2}+2733 . x-11927$ & 0.869 \\
\hline & \multicolumn{2}{|l|}{ PD vs Lower Endoscopy } \\
\hline & Trendline Equation $^{\mathrm{b}}$ & $R$-squared ${ }^{\mathrm{b}}$ \\
\hline Maine & $y=-0.001 x^{4}+0.349 x^{3}-36.45 x^{2}+1680 x-28873$ & 0.774 \\
\hline Vermont & $y=-0.000 x^{4}+0.181 x^{3}-19.53 x^{2}+925.2 x-16269$ & 0.822 \\
\hline Kansas & $y=-0.000 x^{4}+0.010 x^{3}-1.302 x^{2}+63.19 x-1070$ & 0.970 \\
\hline Alaska & $y=-0.002 x^{4}+0.461 x^{3}-40.66 x^{2}+1584 . x-23025$ & 0.782 \\
\hline Missouri & $y=-0.000 x^{4}+0.197 x^{3}-18.67 x^{2}+779.5 x-12097$ & 0.961 \\
\hline Arkansas & $y=-0.000 x^{4}+0.068 x^{3}-6.116 x^{2}+238.4 x-3437$ & 0.963 \\
\hline Mississippi & $y=-0.000 x^{4}+0.128 x^{3}-10.98 x^{2}+412.9 x-5756$ & 0.965 \\
\hline South Dakota & $y=0.000 x^{4}-0.077 x^{3}+6.698 x^{2}-257.9 x+3724$ & 0.971 \\
\hline Nebraska & $y=-0.000 x^{4}+0.028 x^{3}-2.611 x^{2}+103.1 x-1490$ & 0.957 \\
\hline Delaware & $y=-0.008 x^{4}+2.274 x^{3}-241.7 x^{2}+11382 x-20030$ & 0.759 \\
\hline United States a & $y=0.002 x^{4}-0.563 x^{3}+51.05 x^{2}-2053 . x+30914$ & 0.994 \\
\hline
\end{tabular}

Notes:

a All 50 states and the District of Columbia.

${ }^{b}$ Polynomial trendline equations and R-squared values were generated using Microsoft Excel. 
medRxiv preprint doi: https://doi.org/10.1101/2020.11.10.20229450; this version posted November 13 , 2020. The copyright holder for this preprint (which was not certified by peer review) is the author/funder, who has granted medRxiv a license to display the preprint in perpetuity.

It is made available under a CC-BY 4.0 International license .

As shown in Figures $1 \mathrm{a}-\mathrm{b}$ and the tables, there is a inverse association between PD incidence and smoking for the U.S., but there is no association between PD and smoking for the ten states. As can be seen in Table 1, for PD incidence verses smoking, the $R^{2}$ for the United States was 0.714 and ranged from a low of 0.004 for South Dakota to 0.613 for Mississippi. The average $R^{2}$ for the ten states was 0.357 .

As shown in Figures 2a-b and Table 1, there was no correlation between PD incidence and lower endoscopy utilization for the U.S. and for most of the ten states when the fitting curve examined in the regression analysis was linear. The $R^{2}$ for the United States was 0.579 and ranged from a low of 0.349 for Delaware to 0.715 for Arkansas. The average $R^{2}$ for the ten states was 0.588 .

As can be seen from Tables 2-4, the best model fit to the data for PD verses lower endoscopy is a 3rd order polynomial. As shown in Table 3, the $\mathrm{R}^{2}$ for the United States was 0.971 and ranged from a low of 0.709 for Alaska to 0.970 for Kansas. The average $R^{2}$ for the ten states was 0.878 .

\section{DISCUSSION}

The results presented here indicate that there is a strong positive correlation between PD incidence and lower endoscopy utilization. It seems likely that the inverse association between PD and smoking is confounded by lower endoscopy utilization.

The inverse association between PD and smoking is not seen in ages $\geq 75$ years [16]; and the U.S. Preventive Services Task Force (USPSTF) recommends CRC screening for ages 50-75 years [17], further suggesting confounding by lower endoscopy utilization.

Lower endoscopy utilization reduces CRC risk [11-13]. Persons with PD have a decreased risk of CRC when compared to persons without PD [18-20], although this decreased risk is not seen in persons diagnosed with PD at an age of $\geq 75$ years [18]. Since the USPSTF recommends CRC screening for ages 50-75 years [17], it seems possible that the inverse association between PD and CRC risk is also confounded by lower endoscopy utilization.

It may be that both the inverse association between PD and smoking and the inverse association between PD and CRC are confounded by the positive correlation between PD and lower endoscopy utilization. A biological explanation for a positive association between PD and lower endoscopy utilization is provided by the etiology of PD and suggests that iatrogenic transmission of PD pathology may be occurring.

A limitation of the present study is that the characteristics of the population base may not have remained unchanged throughout the study period. Other limitations include the smoking and lower endoscopy percentages provided by the CDC, which are estimates based on the Behavioral Risk Factor Surveillance System (BRFSS), and the PD incidence rates provided by the IHME, which are also estimates. Another 
medRxiv preprint doi: https://doi.org/10.1101/2020.11.10.20229450; this version posted November 13, 2020. The copyright holder for this preprint (which was not certified by peer review) is the author/funder, who has granted medRxiv a license to display the preprint in perpetuity. It is made available under a CC-BY 4.0 International license.

limitation is that the column variable for current smoking was (_RFSMOK2) for 2004, but it was (_RFSMOK3) for all other years. Another limitation is that covariates of lower endoscopy utilization cannot be excluded.

\section{CONCLUSIONS}

The present study concludes that there is a strong positive correlation between PD incidence and lower endoscopy utilization at a population level, reaffirming the findings of the previous study. The results suggest that the inverse association between PD and smoking is confounded by a positive association between PD and lower endoscopy utilization. Further investigation of the relationship between PD and lower endoscopy utilization is warranted and may provide a means for reducing PD incidence.

\section{ACKNOWLEDGMENTS}

The insight of Emily E. Davis was instrumental in the conception of this study. 
medRxiv preprint doi: https://doi.org/10.1101/2020.11.10.20229450; this version posted November $13,2020$. The copyright holder for this preprint (which was not certified by peer review) is the author/funder, who has granted medRxiv a license to display the preprint in perpetuity.

It is made available under a CC-BY 4.0 International license.

\section{REFERENCES}

1. Dorsey ER, Sherer T, Okun MS, Bloem BR. The Emerging Evidence of the Parkinson Pandemic. J Parkinsons Dis. 2018;8(s1):S3-S8. doi:10.3233/JPD-181474.

2. GBD 2016 Parkinson's Disease Collaborators. Global, regional, and national burden of Parkinson's disease, 1990-2016: a systematic analysis for the Global Burden of Disease Study 2016. Lancet Neurol. 2018;17(11):939-953. doi:10.1016/S1474-4422(18)30295-3.

3. Chen H, Ritz B. The Search for Environmental Causes of Parkinson's Disease: Moving Forward. $J$ Parkinsons Dis. 2018;8(s1):S9-S17. doi:10.3233/JPD-181493.

4. Li X, Li W, Liu G, Shen X, Tang Y. Association between cigarette smoking and Parkinson's disease: A meta-analysis. Arch Gerontol Geriatr. 2015;61(3):510-516. doi:10.1016/j.archger.2015.08.004.

5. Sanford NN, Sher DJ, Butler S, et al. Cancer Screening Patterns Among Current, Former, and Never Smokers in the United States, 2010-2015. JAMA Netw Open. 2019;2(5):e193759. Published 2019 May 3. doi:10.1001/jamanetworkopen.2019.3759.

6. Carey RN, El-Zaemey S. Lifestyle and occupational factors associated with participation in colorectal cancer screening among men and women in Australia. Prev Med. 2019;126:105777. doi:10.1016/j.ypmed.2019.105777.

7. Kim EY, Shim YS, Kim YS, Lee SP, Ko KD, Choi WJ. Adherence to general medical checkup and cancer screening guidelines according to self-reported smoking status: Korea National Health and Nutrition Examination Survey (KNHANES) 2010-2012. PLoS One. 2019;14(10):e0224224. Published 2019 Oct 22. doi:10.1371/journal.pone.0224224.

8. Carreras G, lannucci L, Costa G, Chellini E, Gorini G. Are smokers less likely to seek preventive healthcare measures in Italy?. Eur J Cancer Prev. 2018;27(5):507-513.

doi:10.1097/CEJ.0000000000000357.

9. Aguado Loi CX, Adegoke KK, Gwede CK, Sappenfield WM, Bryant CA. Florida Populations Most at Risk of Not Being Up to Date With Colorectal Cancer Screening. Prev Chronic Dis. 2018;15:170224. doi: $10.5888 /$ pcd15.170224.

10. Centers for Disease Control and Prevention (CDC). Vital signs: colorectal cancer screening test use-United States, 2012. MMWR Morb Mortal Wkly Rep. 2013;62(44):881-888.

11. Dekker E, Rex DK. Advances in CRC Prevention: Screening and Surveillance. Gastroenterology. 2018;154(7):1970-1984. doi:10.1053/j.gastro.2018.01.069. 
12. Schmidt C. Colonoscopy vs sigmoidoscopy: new studies fuel ongoing debate. J Nat/ Cancer Inst. 2012;104(18):1350-1351. doi:10.1093/jnci/djs406.

13. Navarro M, Nicolas A, Ferrandez A, Lanas A. Colorectal cancer population screening programs worldwide in 2016: An update. World J Gastroenterol. 2017;23(20):3632-3642.

doi:10.3748/wjg.v23.i20.3632.

14. Global Burden of Disease Collaborative Network. Global Burden of Disease Study 2019 (GBD 2019) Results. Seattle, United States: Institute for Health Metrics and Evaluation (IHME), 2020. Available from http://ghdx.healthdata.org/gbd-results-tool. (Accessed November 4, 2020).

15. Centers for Disease Control and Prevention (CDC). BRFSS Web Enabled Analysis Tool (WEAT). Available from https://www.cdc.gov/brfss/data_tools.htm. (Accessed November 4, 2020).

16. Ritz B, Ascherio A, Checkoway $\mathrm{H}$, et al. Pooled analysis of tobacco use and risk of Parkinson disease. Arch Neurol. 2007;64(7):990-997. doi:10.1001/archneur.64.7.990.

17. US Preventive Services Task Force, Bibbins-Domingo K, Grossman DC, et al. Screening for Colorectal Cancer: US Preventive Services Task Force Recommendation Statement. JAMA. 2016;315(23):2564-2575. doi:10.1001/jama.2016.5989.

18. Boursi B, Mamtani R, Haynes K, Yang YX. Parkinson's disease and colorectal cancer risk-A nested case control study. Cancer Epidemiol. 2016;43:9-14. doi:10.1016/j.canep.2016.05.007.

19. Xie X, Luo X, Xie M. Association between Parkinson's disease and risk of colorectal cancer. Parkinsonism Relat Disord. 2017;35:42-47. doi:10.1016/j.parkreldis.2016.11.011.

20. Liao K-F, Lin C-L, Lai S-W. Parkinson's disease and risk of colorectal cancer: A population-based case-control study in Taiwan. Neurology Asia. 2017; 22: 133-8. 